\title{
Harvesting microalgae using activated sludge can decrease polymer dosing and enhance methane production via co-digestion in a bacterial-microalgal process
}

Wágner, Dorottya Sarolta; Radovici, Maria; Smets, Barth F.; Angelidaki, Irini; Valverde Pérez, Borja; Plósz, Benedek G.

Published in:

Algal Research

Link to article, DOI:

10.1016/j.algal.2016.10.010

Publication date:

2016

Document Version

Peer reviewed version

Link back to DTU Orbit

Citation (APA):

Wágner, D. S., Radovici, M., Smets, B. F., Angelidaki, I., Valverde Pérez, B., \& Plósz, B. G. (2016). Harvesting microalgae using activated sludge can decrease polymer dosing and enhance methane production via codigestion in a bacterial-microalgal process. Algal Research, 20, 197-204.

https://doi.org/10.1016/j.algal.2016.10.010

\section{General rights}

Copyright and moral rights for the publications made accessible in the public portal are retained by the authors and/or other copyright owners and it is a condition of accessing publications that users recognise and abide by the legal requirements associated with these rights.

- Users may download and print one copy of any publication from the public portal for the purpose of private study or research.

- You may not further distribute the material or use it for any profit-making activity or commercial gain

- You may freely distribute the URL identifying the publication in the public portal 
1 Harvesting microalgae using activated sludge can decrease polymer dosing and

2 enhance methane production via co-digestion in a bacterial-microalgal process

Dorottya S. Wágner*, Maria Radovici, Barth F. Smets, Irini Angelidaki, Borja Valverde-Pérez, Benedek Gy. Plósz*

Department of Environmental Engineering, Technical University of Denmark, Miljøvej, Building 113, 2800 Kgs. Lyngby, Denmark

*Corresponding authors: dosaw@env.dtu.dk; beep@env.dtu.dk

\section{Abstract}

8 Third generation biofuels, e.g. biofuels production from algal biomass, have gained attention due to

9 increased interest on global renewable energy. However, crop-based biofuels compete with food 10 production and should be avoided. Microalgal cultivation for biofuel production offers an

11 alternative to crops and can become economically viable when combined with the use of used water resources. Besides nutrients and water, harvesting microalgal biomass represents one of the major costs related to biofuel production and thus efficient and cheap solutions are needed. In bacterialalgal systems, there is the potential to produce energy by co-digesting the two biomasses. We present an innovative approach to recover microalgal biomass via a two-step flocculation using bacterial biomass after the destabilization of microalgae with conventional cationic polymer. A short solids retention time (SRT) enhanced biological phosphorus removal (EBPR) system was combined with microalgal cultivation. Two different bacterial biomass removal strategies were assessed whereby bacterial biomass was collected from the solid-liquid separation after the anaerobic phase and after the aerobic phase. Microalgal recovery was tested by jar tests where three different chemical coagulants in coagulation-flocculation tests $\left(\mathrm{AlCl}_{3}, \mathrm{PDADMAC}\right.$ and Greenfloc 120) were assessed. Furthermore, jar tests were conducted to assess the microalgal biomass recovery by a two-step flocculation method, involving chemical coagulants in the first step and 
24 bacterial biomass used in the second step to enhance the flocculation. Up to $97 \%$ of the microalgal biomass was recovered using $16 \mathrm{mg}$ polymer/g algae and $0.1 \mathrm{~g}$ algae/g bacterial biomass. Moreover, the energy recovery by the short-SRT EBPR system combined with microalgal cultivation was assessed via biomethane potential tests. Up to $560 \pm 24 \mathrm{ml} \mathrm{CH}_{4} / \mathrm{gVS}$ methane yield was obtained by co-digesting bacterial biomass collected after the anaerobic phase and microalgal biomass. The energy recovery obtained from the short-SRT EBPR system is about $40 \%$ of the influent chemical energy.

\section{Keywords}

Green microalgae; enhanced biological phosphorus removal; bioflocculation; co-digestion; energy recovery

\section{Introduction}

Due to the challenges related to greenhouse gas emissions, decreasing fossil fuel reserves and global and national pressure, new solutions are sought to produce renewable energy including the use of biomass for biofuel production. However, first generation biofuels (derived from agricultural crops) are of questionable sustainability as they compete for land with food crops, thereby affecting the global food security [1,2]. Similarly, second generation biofuels, e.g. non-food energy crops (e.g. vegetative grasses or short rotation forests), agricultural and forest residues, compete for land use in some cases and there are technological difficulties related to the conversion processes [1]. Third generation biofuels such as microalgae have the advantages that they can be produced all year round, do not compete food production as they can be grown on non-arable land, have rapid growth rates and the biochemical composition can be manipulated by varying cultivation conditions and strains $[1,3]$. The cultivation of microalgae for biofuel production can be economically viable when 
coupled with wastewater treatment [3-6] which provides the water and nutrients (nitrogen and phosphorous) required for growth [7].

Conventional wastewater treatment has a high energy demand required mainly by the aeration process whereby organic carbon present in wastewater is oxidized to $\mathrm{CO}_{2}$ and nitrification takes place under long sludge ages [8]. This leads to the loss of the energy potential of the activated sludge [9] together with the loss of nutrients (nitrogen and phosphorus) [8]. Short solids retention time (SRT) activated sludge systems propose a solution whereby rather than the oxidization of organic carbon, activated sludge preserves the organic carbon promoting higher potential for energy recovery [10].

Bacterial-algal systems can be coupled with wastewater treatment, whereby nutrients and energy can be recovered [3]. In a novel wastewater resource recovery approach, Valverde-Pérez et al. [11] proposed an enhanced biological phosphorus recovery and removal (EBP2R) process, able to provide optimal culture media for downstream microalgal cultivation. The system referred to as TRENS, consists of a modified short-SRT EBP2R process where an additional solid-liquid separation is included after the anaerobic phase (Fig. S1, Supporting Information, SI). Under anaerobic conditions, phosphorus accumulating organisms (PAO) take up the volatile fatty acids (VFA) from the wastewater and store them as polyhydroxyalkanoates (PHA) intracellularly while releasing intracellular phosphorus (poly-P) [12]. Under aerobic conditions the stored PHA are used to produce energy for biomass growth as well as phosphorus uptake and storage [12].Thus, the effluent water after the solid-liquid separation after the anaerobic phase is rich in phosphorus, whilst the effluent after the solid-liquid separation after the aerobic phase is rich in nitrogen. The shortSRT EBP2R can provide optimal cultivation medium to a downstream photobioreactor (PBR) by mixing the phosphorus and nitrogen rich effluent streams in an optimal ratio. 
69 When microalgal cultivation is coupled with wastewater treatment the lipid content of the microalgae is fairly low (4.9-11.3\%) due to the relatively high nutrients supplied [3,13]. It is energetically favourable to apply anaerobic digestion when the lipid concentration is lower than $40 \%$ [14]. In addition, anaerobic digestion is applicable for biomasses with high moisture content (80-90\%), which makes it suitable for microalgal biomass conversion [1,15]. Thus, anaerobic digestion is the preferred route over biodiesel production when energy recovery is considered from microalgae cultivated on wastewater resources [13]. The nutrient rich effluents of the anaerobic digestion can be used for further cultivation of microalgae [1]. Anaerobic digesters are in many cases available in the existing wastewater treatment plants and biogas production can be increased by co-digestion of microalgae and activated sludge [16]. Nonetheless, not all microalgal species are suitable for biogas production, mainly due to their cell wall structure and their high nitrogen content $[14,17]$

A C/N ratio of $20(\mathrm{~g} / \mathrm{g})$ is suitable for optimal digestion conditions [4,18]. While, in freshwater microalgae it is typically around $10[14,19]$. Many studies proposed co-digestion with other biomass sources, e.g. activated sludge, to improve digestibility by balancing the $\mathrm{C} / \mathrm{N}$ ratio, thereby providing optimal nutrient balance for enhanced methane yield $[3,15,16,18]$. Additionally, the codigestion of various waste lines reduce costs by using a single anaerobic digester unit for digestion of multiple substrates [3].

The major bottleneck of microalgal cultivation for biogas production is the cost related to biomass harvesting [15,20,21]. Energy-intensive and expensive methods, e.g. centrifugation or membrane technologies [20], are only applicable when the biomass is used to produce high value products [21]. Thus simple harvesting methods are required for reliable and safe downstream applications [3]. 
92 Flocculation is an alternative and cheap harvesting method [20,22]. During coagulation the negative surface charge of microalgae, caused largely by the presence of carboxyl groups, is destabilized. This is followed by a second flocculation step whereby aggregates are formed, thus promoting more effective gravity sedimentation [21,23]. Iron or aluminium salts, which form positively charged hydroxides when dissolved in water, are successfully used as coagulants that neutralize the negative algal cells promoting aggregate formation [24]. $\mathrm{AlCl}_{3}$ addition is a common method in wastewater treatment to enhance the coagulation-flocculation process [25]. Nevertheless, aluminium salts require high dosage and the downstream usage is limited due to toxicity [21]. Cationic polymers can induce flocculation of algal biomass by surface charge neutralization or by inter-cellular bridging [24]. The effectiveness of the polymers depends on their size and charge density. Compared to metal salts, polymers usually operate at lower dosages [21]. Flocculation efficiency by polymers declines at high dosages due to restabilisation [20,21]. Bioflocculation has also been proposed: in this case a specific bacteria, fungi or algae are added to the microalgal culture promoting flocculation $[20,26]$.

Bacterial-algal systems have the potential to recover energy through biomass production. Thus, a cost-effective harvesting method is needed whereby the algal and bacterial biomass can be recovered. The objectives of this study are (i) to test the effect of different chemical flocculants on microlagal recovery; (ii) to develop a cost-effective method of harvesting microalgae via a two-step flocculation using cationic polymer for destabilisation of microalgae and bacterial biomass from a short-SRT EBPR system to enhance the aggregation of the algae; (iii) to optimize the cationic polymer dosing; (iv) to assess the effect of different algae/bacterial biomass ratios and the effect of bacterial biomass settleability on algal biomass recovery; and (v) to assess the methane production potential by co-digestion of the harvested bacterial-algal biomass. 


\subsection{Microalgal cultivation and EBPR operation}

\subsubsection{Algal biomass used for pre-testing different coagulants}

We cultivated a mixed green microalgal consortium consisting mainly of Chlorella sorokiniana and Scenedesmus sp. (see Wágner et al. [27]). The consortium was cultivated with effluent water from the Lundtofte WWTP (Denmark). Ammonium and phosphorus were spiked to reach $20 \mathrm{mg} / \mathrm{L} \mathrm{NH}_{4}-$ $\mathrm{N}$ and $2.75 \mathrm{mg} / \mathrm{L} \mathrm{PO}_{4}-\mathrm{P}$ (16 N-to-P ratio) in the microalgal batch cultivation. $2 \mathrm{~L}$ glass reactors were used to cultivate the algae with constant stirring at $180 \mathrm{rpm}$ using magnetic stirrers and with aeration with $\mathrm{CO}_{2}$ enriched air $\left(5 \% \mathrm{CO}_{2}\right)$ at a flow rate of $10 \mathrm{~L} / \mathrm{h}$. Light was supplied from the two sides of the batches with fluorescent lamps (18 W, GroLux, Sylvania®, USA), providing $160 \mu$ mol photons $\mathrm{m}^{-2} \mathrm{~s}^{-1}$ continuously. The temperature in the room was regulated at $20{ }^{\circ} \mathrm{C} .80 \%$ of the algal suspension was removed every 2-3 days from the batch reactor and the reactor was refilled with new effluent water. The $\mathrm{pH}$ of the algal culture varied between 6.84 and 7.95 during the experiments. The TSS of the algal suspension used for flocculation varied between 0.29 and 0.37 g/L. The algal TSS and OD values used for each flocculation experiment are reported in Table S1, SI.

\subsubsection{Algal and bacterial biomass used for the two-step flocculation}

The same mixed green microalgal consortium was used in the two-step flocculation experiments. The microalgal culture was grown on effluent water from a laboratory scale EBPR system [28] operated at 3-3.5 days SRT as a sequencing batch reactor (SBR) (fed with pre-clarified wastewater from Lundtofte WWTP, Denmark). The ammonium and ortho-phosphate concentrations were adjusted to an N/P molar ratio of 17 in the beginning of each microalgal batch (adjusted to $23 \mathrm{mg} / \mathrm{L}$ 
$\mathrm{NH}_{4}-\mathrm{N}$ and $3 \mathrm{mg} / \mathrm{L} \mathrm{PO}_{4}-\mathrm{P}$ ). $1.5 \mathrm{~L}$ glass reactors were used to cultivate the algae with constant aeration with $\mathrm{CO}_{2}$ enriched air $\left(5 \% \mathrm{CO}_{2}\right)$ at a flow rate of $10 \mathrm{~L} / \mathrm{h}$. Light was supplied from the top of the batch reactor continuously with a custom-built lamp, providing $500 \mu \mathrm{mol}$ photons $\mathrm{m}^{-2} \mathrm{~s}^{-1}$, with a metal-halide light bulb (OSRAM $\odot$, Germany). The reactors were kept at room temperature. The $\mathrm{pH}$ of the algal culture varied in the range of $7-8.5$ during the experiments. $60 \%$ of the algal suspension was removed every 2-3 days and the batch reactor was refilled with new effluent water from the EBPR system (adjusted to N/P molar ratio of 17). The TSS of the algal suspension varied in the range of $0.27-0.52 \mathrm{~g} / \mathrm{L}$ during the experiments. The algal TSS and OD values used for each flocculation experiment are reported in Table S1, SI. The bacterial biomass was taken from the short-SRT EBPR system using two biomass removal strategies: i) bacterial biomass removed at the end of the anaerobic phase; ii) bacterial biomass removed at the end of the aerobic phase. Samples for the biogas tests were taken during the course of 1 month, whilst the samples for the flocculation tests were taken throughout a 6 months period. Considering the use of real wastewater and the length of the experiments, results obtained can represent the effect of variability in used water resources, thereby allowing inferring experimental results more representative to real systems.

\subsection{Flocculation and bioflocculation tests}

\subsubsection{Pre-testing of flocculation with different coagulants}

The coagulation aids included $\mathrm{AlCl}_{3}$ (Sigma Aldrich), the cationic biopolymer Greenfloc 120 (Hydra 2002, Hungary) and the cationic polymer Poly(diallyldimethylammonium chloride) (PDADMAC) (Sigma Aldrich). Jar testing was done based on the standard practice for coagulationflocculation jar test of water [29]. Each flocculation test included the parallel testing of six $1 \mathrm{~L}$ jars using a mixing device with a rotating impeller mixing each jar. In each jar, a chosen coagulation aid was spiked at varying concentrations, while mixing. During the first 2 min, a high mixing rate (150 
rpm) was applied to evenly mix the added coagulants with the algae. This step was followed by a slow mixing at $25 \mathrm{rpm}$ to let the particles flocculate for $10 \mathrm{~min}$. After the flocculation, the mixing was stopped and the impellers were removed from the solution to initiate 30 min settling.

\subsubsection{Two-step flocculation}

Two flocculation methods were tested in $1 \mathrm{~L}$ jars: i) the bacterial biomass was used to flocculate algae and ii) a two-step flocculation was tested where in the first step the algae were coagulated first with the cationic polymer PDADMAC and then bacterial biomass was added in the second step to enhance the flocculation. In the first case, high mixing was applied at $100 \mathrm{rpm}$ for $2 \mathrm{~min}$ and different slow mixing times (i.e. $10 \mathrm{~min}, 1 \mathrm{~h}$ and $3 \mathrm{~h}$ ) were tested at $20 \mathrm{rpm}$. For the two-step flocculation method the duration of flocculation is given in Table 1. Both methods were followed by 30 min settling period.

\section{$<$ Table 1>}

\subsection{Biomethane potential}

\subsubsection{Samples combinations for biomethane potential assays}

The settled biomass samples were collected after the two-step flocculation tests and kept at $-20{ }^{\circ} \mathrm{C}$ until further use. Additionally to the flocculated samples, microalgal and bacterial biomass were collected to assess the biomethane potential (BMP) of the single biomasses and their combination without polymer. All the samples were kept frozen until the BMP assays were set up. In total, eight different scenarios were assessed in BMP assays using triplicates: algae, algae + polymer (20 mg polymer/g algae), activated sludge (AS) alone (taken after the aerobic and anaerobic phase), $\mathrm{AS}_{\mathrm{AE}} / \mathrm{AS}_{\mathrm{AN}}+$ algae (ratio 0.1 of g algae/g AS) and lastly $\mathrm{AS}_{\mathrm{AE}} / \mathrm{AS}_{\mathrm{AN}}+$ algae + polymer (ratio 0.1 of g algae/g AS, $20 \mathrm{mg}$ polymer/g algae). The SRT of the EBPR system was 3.5 days in all samples 
used for BMP tests. The amount of substrate and inoculum as well as the total solids (TS) and volatile solids (VS) concentrations of each sample are reported in Table S2, SI. The composition of the substrates is reported in Table S3, SI.

\subsubsection{Biomethane potential assays set up}

The set up for the BMP assays was adapted from Angelidaki et al. [30]. Inoculum for the assay test was taken from the mesophilic anaerobic digester of Lundtofte WWTP. The defrosted biomass samples were added together with the inoculum to $1200 \mathrm{ml}$ bottles, flushed with $\mathrm{N}_{2}$ for 5 minutes, closed with air tight rubber stoppers, sealed with screw caps and stored at mesophilic conditions at $37{ }^{\circ} \mathrm{C}$. Avicel $\mathrm{pH}-101$ was used as substrate for positive control and DI water as substrate for negative control. The methane concentration produced in the bottles was measured every 2-3 days using the GC-2010 (Shimadzu, Japan). On each measurement day a calibration curve was set up using 5, 10, 40 and $60 \%$ methane content to be able to relate the methane content of the samples. Each time 50-100 $\mu \mathrm{L}$ sample was taken from the headspace using a pressure syringe and was injected into the GC.

\subsection{Analytical methods and calculations}

The optical density (OD) at $750 \mathrm{~nm}$ was measured in the initial algae suspension and in the bacterial biomass and was monitored during the 30 min settling by taking samples $5 \mathrm{~cm}$ below the liquid surface (approximately at $700 \mathrm{ml}$ in the $1 \mathrm{~L}$ jar) to maintain uniform sampling in all experiments (adapted from [31]). In case the biomass blanket height was above $700 \mathrm{ml}$, due to poor settling of bacterial biomass, the final OD sample at 30 min was taken from the supernatant above the biomass height in order to calculate microalgal biomass recovery. OD samples were collected in 24 well microplates and OD measurements were conducted in the end of each jar test using Synergy Mx 
205 (based on [32]):

206

207

208

209

210

211

212 Wang et al. [35]:

Microplate Reader ${ }^{\circledR}$ (Biotek). The recovery was calculated based on the following expression

Recovery $(\%)=\frac{O D_{750 i n i t}-O D_{750,30 \mathrm{~min}}}{O D_{750 i n i t}} * 100$

Eq. 1

where $\mathrm{OD}_{750 \text { init }}$ is the OD of the initial suspension, $\mathrm{OD}_{750,30 \mathrm{~min}}$ is the OD measured at the end of the settling phase. Average recovery and the standard deviation were calculated based on the last three measurement points of the 30 min settling period.

The price of harvesting the microalgal biomass using different coagulants was calculated. The estimations were based on the price of $\mathrm{AlCl}_{3}$, Greenfloc 120 and PDADMAC reported by the suppliers (see section 2.2.1) in 2014, when the experiments were conducted.

Total suspended solids (TSS), volatile suspended solids (VSS) and TS and VS of the algae and bacterial biomass were measured based on standard methods [33]. Sludge volume index (SVI) of the bacterial biomass was measured in 1L cylinder based on Ekama et al. [34]. Total nitrogen and phosphorus and COD measurements in the samples were done using commercial test kits (HachLange(C, USA) and measured with spectrophotometer DR2800 (Hach-Lange).

The average methane yield and the standard deviation were calculated based on triplicate batch tests conducted for each scenario. Each replicate was collected on a different day as the amount of bacterial and algal biomass was not enough for more than one flocculation test.

We calculated the methane yield produced during the co-digestion of algae and bacteria based on

Calculated methane yield $=Y_{s} * C_{s}+Y_{a} * C_{a}$

Eq. 2 
where $Y_{s}$ and $Y_{a}$ is the measured methane yield of bacterial biomass and algae produced individually and $\mathrm{C}_{\mathrm{s}}$ and $\mathrm{C}_{\mathrm{a}}$ is the mixing fraction of bacteria and algae in the co-digestion scenario. These numbers were confronted with the measured methane yields of the co-digestion scenarios, assessing the synergistic effect of co-digestion, and results are shown in section 3.3.

First-order kinetics is used to estimate the hydrolysis constant $\left(\mathrm{k}_{\mathrm{h}}\right)$ and the ultimate methane production $\left(\mathrm{B}_{\infty}\right)$ based on Angelidaki et al. [30] and Ge et al. [36]:

$$
B=B_{\infty}\left(1-e^{-k_{h} * t}\right) \quad \text { Eq. } 3
$$

where $\mathrm{B}$ is the methane produced at a given time.

Student's t-tests were conducted, based on the triplicate samples, to compare the measured methane yields for the different digestion scenarios, using SigmaPlot (USA).

\section{Results and discussion}

\subsection{Flocculation of microalgae using different coagulants}

$\mathrm{AlCl}_{3}$ was effective for harvesting the microalgae, and dosing at $100 \mathrm{mg} \mathrm{AlCl}_{3} / \mathrm{g}$ algae resulted in a recovery of $97 \%$ after 30 min settling time (Fig. 1a). A different trend in the recovery was obtained when using polymers. The optimum Greenfloc 120 dosing was $30 \mathrm{mg}$ GF/g algae, yielding 84\% recovery, based on visual observations (Fig. 1a). However, when a higher polymer concentration was added to the suspension, the recovery decreased. This is the likely consequence of the restabilisation process whereby increasing the amount of positive charges will result in repulsion between the aggregates [21]. Similarly, when coagulation was induced by the addition of PDADMAC an optimum recovery of $92 \%$ was found at the intermediary dose of ca. $27 \mathrm{mg}$ PDADMAC/g algae (Fig. 1a). 
246 The optimal dosage of $\mathrm{AlCl}_{3}$ is within the reported range for aluminium salts, 85 - $503 \mathrm{mg}$ 247 aluminium salt/g algae [37,38]. The optimal cationic polymer dosage reported in the literature, (e.g. 248 Roselet et al. [21], 19.23 - $57.69 \mathrm{mg}$ polymer /g algae) is in agreement with the range found in our 249 study. Restabilisation, as we observed, is not always reported: whilst some observed restabilisation 250 (e.g. [21,39]), others (e.g. [40]) found no restabilisation as the amount of polymer was increased. 251 Gerde et al. [31] observed restabilisation at lower biomass concentrations (0.05-0.2 g/L), whilst at 252 high biomass concentrations ( $1 \mathrm{~g} / \mathrm{L})$ this effect was not visible within the same dosing range. This 253 may be important when considering cultivation conditions and reactor operation. Depending on the 254 cultivation conditions, i.e. open ponds or closed photobioreactors, the biomass concentration during 255 the cultivation can vary from $0.1-4 \mathrm{~g} / \mathrm{L}$ [41]. The maximum biomass concentration that can be 256 reached in open ponds and closed photobioreactors is $1 \mathrm{~g} / \mathrm{L}$ and $4 \mathrm{~g} / \mathrm{L}$, respectively [42]. In this 257 study, the system resembles an open pond reactor with comparably low biomass concentration, 258 which may lead to algae restabilisation.

259 The optimum $\mathrm{AlCl}_{3}$ dosage would result in a cost of approximately $6000 \mathrm{EUR} / \mathrm{ton}$ algae harvested 260 (Fig. 1b), whist the use of Greenfloc 120 and PDADMAC at an optimal dose would be $30-60$ 261 times lower, about 100 and 900 EUR/ton algae, respectively (Fig. 1b). Moreover, the use of 262 aluminium salts may pose negative effects in terms of downstream recycling of the effluent water 263 [43] that can limit further usage of the biomass for land application or biogas production [44] due to 264 their substantial toxic effects [45]. However, according to Udom et al. [46] polymers have 265 substantial environmental and economic costs related to their production process. The greenhouse 266 gas emission and the energy consumption costs related to the production of polymers are found to 267 be nearly ten times higher than for ferric chloride [46]. Thus even though we save on the operational costs due to the lower dosage, there are additional energy-expensive costs related to the 
use of polymers. Recovery rates obtained with PDADMAC and Greenfloc are not significantly different (based on t-test, $\mathrm{P}>0.05$ ). Due to the similar performance and the easier access on the market (Greenfloc had limited availability for research purposes) PDADMAC was chosen for further assessment.

\subsection{Bioflocculation of microalgae - an innovative approach}

Flocculation of microalgae with bacterial biomass by 10 min flocculation time resulted in $40 \%$ recovery (Fig. S2, SI). Furthermore, increasing the mixing time did not improve the microalgal recovery (Fig. S2, SI), in contrast to the observations by Manheim and Nelson [26]. Alternatively, we considered addition of cationic polymer as coagulation aid to destabilise the microalgae before the addition of bacterial biomass and to enhance the separation of microalgae.

Different concentrations of polymer addition were tested (Fig. 2a). With increasing polymer concentrations the microalgal recovery increased as well. This suggests that as the algal cells aggregate into larger particles the probability of collision with the bacterial biomass flocs can significantly increase, thereby increasing flocculation efficiency. No restabilisation effect was observed at the assessed dosing, likely due to the high concentrations of bacterial biomass addition, in accordance with the findings of Gerde et al. [31]. However, we note that there might be restabilisation at higher polymer dosages [31]. Recovery rate ca. 97\% was obtained using a polymer dosage of $16 \mathrm{mg} / \mathrm{g}$ algae at a $0.1 \mathrm{~g}$ algae/g bacterial biomass ratio. Using bacterial biomass and polymer for the coagulation-flocculation can reduce the polymer dosing by $40 \%$ compared to the scenario when only algae was flocculated with the cationic polymer, PDADMAC (Fig. 2b). Consequently, harvesting costs are reduced.

$<$ Figure 2 $>$ 
The mixing ratio was fixed at $0.1 \mathrm{~g}$ algae/g bacterial biomass for most experiments. With increasing algae-to-bacterial biomass ratio, maintaining the same polymer dosage (16 mg polymer/g algae), the microalgal recovery decreased, on average, with more than $50 \%$ (Fig. 3). This shows the importance of assessing the optimum polymer dosing for the operational algal-to-bacterial biomass mixing ratio. However, some deviation from the optimum ratio will not compromise the recovery as we find similar recovery at $0.2 \mathrm{~g}$ algae/g bacterial biomass.

\section{$<$ Figure 3 $>$}

The flocculation efficiency of microalgae and the required dosing of coagulants and flocculants can be influenced by factors, such as mixing time [26], $\mathrm{pH}$ [40] or the growth stage and age of the microalgal culture [20]. Autoflocculation due to the increase of $\mathrm{pH}$ typically occurs above $\mathrm{pH}=10$ $[32,47]$. Therefore, the effect of $\mathrm{pH}$ should be negligible as it was kept below 8.5 during the experiments (section 2.1.2). We assume that the algae samples were in similar physiological state for all flocculation experiments as the algal biomass was harvested every 2-3 days. Moreover, it is reported in the literature that a certain concentration of inorganic coagulant can result in different recovery for different microalgal species [21,48]. Thus in a mixed microalgal culture if the dominance of the microalgal species changes the flocculation efficiency can potentially change. However, microbial community was not monitored in this study. In addition, this effect can be potentially compensated by the addition of the bacterial biomass as it can hinder the restabilisation effect in the tested dosing range.

The settleability of the bacterial biomass varied in the EBPR system due to filamentous bulking, which could have affected the observable flocculation efficiency. During the experiments, the SVI (an indicator of the settling characteristics of the bacterial biomass [34]) varied between 180 and $760 \mathrm{ml} / \mathrm{g}$, which allowed us to test the effect of bacterial biomass settling on the recovery of 
microalgal biomass. The separation of the bacterial-microalgal biomass after flocculation might be limited if bulking (high SVI) bacterial biomass is used (Fig. S3, SI). Even though the separation of the bacterial-algal biomass deteriorates, the recovery of microalgae is not affected by the increased SVI of bacterial biomass (Fig. 4). Thus the bacterial composition has no particular effect on the microalgal recovery. Additionally, the commonly believed particle screening effect of filamentous bacteria, whereby filaments are the backbone of flocs, responsible for incorporating colloidal particles into the floc structure [49] does not seem to play a significant role in the flocculation of algal biomass. Instead, the surface charge of the biomass may control the flocculation behaviour. The negative surface charge of the biomass comes in contact with the positive charges of the polymer that is attached to the algae, thereby promoting aggregate formation. Despite the low impact on microalgal recovery, from an operational perspective, the abundance of filamentous organisms in bacterial biomass is an important factor, responsible for causing foaming in anaerobic digesters, that could deteriorate digester performance [50].

\section{$<$ Figure 4>}

\subsection{Co-digestion of algal and bacterial biomass}

The biomethane potential (BMP) obtained after 27 days of digestion of the microalgal biomass is $331 \pm 76 \mathrm{ml} \mathrm{CH}_{4} / \mathrm{gVS}$ (Fig. 5). The methane yield obtained by digesting solely microalgal biomass is reported in a wide range in the literature (143-497 $\left.\mathrm{ml} \mathrm{CH}_{4} / \mathrm{gVS}\right)[2,18]$, which also corresponds to the results obtained in this study. Wang and Park [13] report slightly lower yields (230 ml $\mathrm{CH}_{4} / \mathrm{gVS}$ ) when digesting Chlorella sp., whereas Olsson et al. [51] report similar values when digesting algae (mixed green microalgal culture - approx. $370 \mathrm{ml} \mathrm{CH}_{4} / \mathrm{gVS}$ ). In this study, we obtain similar methane yields without the pre-treatment of algae to those that are reported with different pre-treatment options in the literature (105-336 $\mathrm{ml} \mathrm{CH}_{4} / \mathrm{gVS}$ ) [52]. Nevertheless, 
Anbalagan et al. [53] showed that pre-treatment does not always result in higher BMP as, e.g., the nutrient balance and type of algae are also important factors affecting the methane yield. In addition, the variations reported through the literature might be due to the dominance of different species in a mixed culture, which can affect the biogas potential [51]. The addition of polymer does not significantly affect the biomethane potential of the microalgae.

\section{$<$ Figure 5 $>$}

The biomethane potential of the biomass removed after the aerobic phase is $363 \pm 68 \mathrm{ml} \mathrm{CH} 4 / \mathrm{gVS}$, whereas, for biomass removed after the anaerobic phase is $449 \pm 17 \mathrm{ml} \mathrm{CH} 4 / \mathrm{gVS}$ (Fig. 5, Table 2). The difference between these two digestion scenarios is not significant. Kuglarz et al. [54] reported generally lower methane yields compared to our measurements when digesting bacterial biomass, taken from a conventional wastewater treatment plant, even after pre-treatment (approx. $270 \mathrm{ml}$ $\mathrm{CH}_{4} / \mathrm{gVS}$ ). It is reported by Bolzonella et al. [55] that higher biogas potential is reached when bacterial biomass is taken from shorter SRT (8 d in their study) wastewater treatment systems compared to systems with longer SRT (45 d in their study). Literature is relatively scarce in regard to assessing the biogas potential of short-SRT bacterial biomass. The study by Ge et al. [36] reports similar results to those obtained with the biomass removed after the aerobic phase in our study (BMP: $306.4 \pm 12.6-332.4 \pm 19.7 \mathrm{ml} \mathrm{CH}_{4} / \mathrm{gVS}$ ). These BMP values are significantly lower than that obtained using bacterial biomass collected after the anaerobic phase in the short-SRT EBP2R process.

The hydrolysis rate and the ultimate biomethane potential were estimated by fitting Eq. 3 on the data obtained during the 27-day long digestion tests (Table 2). The $k_{h}$ for the anaerobic digestion of microalgae found in this study is higher than those reported in the literature [56]. Only Ge et al. [36] 
report $k_{h}$ values $\left(0.19 \pm 0.02-0.22 \pm 0.04 \mathrm{~d}^{-1}\right)$ that are comparable to those obtained in this study with aerobically and anaerobically harvested bacterial biomass.

\section{$<$ Table 2>}

The co-digestion of the bacterial biomass removed after the aerobic phase and microalgal biomass resulted in higher amount of methane produced than by digesting them individually (not significantly different, $\mathrm{P}>0.05$ ). Whereas, the co-digestion of algae with bacterial biomass collected after the anaerobic phase resulted in significantly higher methane yields compared to digesting the algal and bacterial biomass separately, based on the results of the t-test (Table S4, SI). Values of the measured yield obtained with and without polymer are $424 \pm 14$ (Algae $+\mathrm{AS}_{\mathrm{AE}}+$ poly) and $400 \pm 22$ (Algae $+\mathrm{AS}_{\mathrm{AE}}$ ), respectively, expressed as $\mathrm{ml} \mathrm{CH}_{4} / \mathrm{gVS}$. This is approximately $10 \%$ higher than that reported in the literature [51]. The calculated methane yield (Eq. 2) for the co-digestion scenario with the bacterial biomass collected after the aerobic phase is $360 \pm 62 \mathrm{ml} \mathrm{CH} / \mathrm{gVS}$ (Table 2). We find no significant difference ( $\mathrm{P}>0.05$ ) between calculated (based on Eq. 2) and measured values. Thus, our results suggest no synergistic effect when co-digesting algae and bacterial biomass removed after the aerobic phase, in agreement with the literature [15]. The calculated methane yield (Eq. 2) for the co-digestion scenario with the bacterial biomass collected after the anaerobic phase is $437 \pm 17 \mathrm{ml} \mathrm{CH}_{4} / \mathrm{gVS}$ (Table 2). Values of the measured yield obtained with and without polymer are 528 \pm 28 (Algae $+\mathrm{AS}_{\mathrm{AN}}+$ poly) and 560 \pm 24 (Algae $+\mathrm{AS}_{\mathrm{AN}}$ ), respectively, expressed as $\mathrm{ml} \mathrm{CH}_{4} / \mathrm{gVS}$. Thus, we find that the measured values are significantly higher $(\mathrm{P}<0.05)$ than the calculated values based on Eq. 2. These results suggest that - as opposed to using the bacterial biomass removed after the aerobic phase - there may be synergistic effects of co-digesting algae with biomass removed after the anaerobic phase, compared to digesting them individually. Furthermore, the biomethane potential of the co-digestion was significantly higher $(\mathrm{P}<0.05)$ with bacterial biomass taken after the anaerobic phase than with biomass taken from the aerobic phase 
383

384

(Fig. 5, Table 2). The higher co-digestion potential with bacterial biomass removed after the anaerobic phase could be related to their content of PHA. It is well known that PAO store VFA in the form of PHA under anaerobic conditions [12] which is a more easily available substrate for the digestion than other organic materials, e.g. the cell wall. Interestingly, we do not find significant difference between the single digestion of biomass taken after the anaerobic and aerobic phase. This suggests that the single digestion of the bacterial biomass may be nutrient limited, thereby producing less methane. Whereas, co-digestion with a nutrient rich biomass, e.g. microalgae, could provide the additional nutrients needed to digest the increased organic carbon content, resulting in higher methane potential. Additionally, other studies suggest that the increased micronutrients content added with the microalgal biomass can improve the biogas potential when co-digesting algae with bacterial biomass [51]. Presence of the cationic polymer after the flocculation did not affect the co-digestion potential (no significant effect, $\mathrm{P}>0.05$ ), in agreement with the literature [23] (Table 2).

\section{<Figure 6>}

It was estimated that $0.4 \pm 0.02 \mathrm{~g} \mathrm{COD}_{\mathrm{CH} 4} / \mathrm{g} \mathrm{COD}_{\text {inf }}$ and $0.36 \pm 0.07 \mathrm{~g} \mathrm{COD}_{\mathrm{CH} 4} / \mathrm{g} \mathrm{COD}_{\text {inf }}$ energy can be recovered in the form of methane, for the anaerobic and aerobic bacterial biomass removal scenarios, respectively. These results are considerably higher than that obtained for conventional activated sludge systems $\left(0.07 \pm 0.06 \mathrm{~g} \mathrm{COD}_{\mathrm{CH} 4} / \mathrm{g} \mathrm{COD}_{\text {inf }}\right)$ and are comparable to other short-SRT activated sludge systems $\left(0.36 \pm 0.08 \mathrm{~g} \mathrm{COD}_{\mathrm{CH} 4} / \mathrm{g} \mathrm{COD}_{\mathrm{inf}}\right)$ [57]. The assessment of the distribution of the influent COD (Fig. 7) shows that not only approximately $40 \%$ of the influent COD is recovered as methane, but the EBPR system effectively removes most of the influent COD leaving up to maximum $10 \%$ as inert material in the effluent wastewater. Compared to other short-SRT systems, these results show significantly lower loss of COD in the effluent while directing comparable amounts into the biomass $[9,57,58]$. This facilitates downstream unit process operation, 
e.g. microalgal cultivation or autotrophic nitrogen removal based technologies. Taken together, our results suggest that there is an increased methane potential of the co-digestion of bacterial biomass generated through the short-SRT EBPR system and microalgal biomass. Furthermore, the associated environmental costs are lower as pre-treatment of the biomass is not necessary and less energy is invested for pollutant removal compared to systems with long solid retention times. Moreover, the COD recovered through the EBPR process is comparable to that found in the literature for other short-SRT systems, leaving up to maximum $10 \%$ as inert material in the effluent water.

\section{$<$ Figure 7 >}

\section{Conclusions}

In this study we assessed an innovative bioflocculation method to harvest microalgal biomass and evaluated the potential to produce methane through digestion and co-digestion of the recovered microalgal biomass with bacterial biomass derived from an EBPR system. We found that:

- The cationic polymer (PDADMAC) proved to be a cost-efficient way to harvest microalgal biomass resulting in 92\% recovery with $27 \mathrm{mg}$ polyelectrolyte/g algae dosing.

- An innovative bioflocculation method was introduced to separate microalgal biomass. Bacterial biomass was used as a flocculant after the destabilization of microalgae with cationic polymer, whereby up to $97 \%$ recovery was reached with $16 \mathrm{mg}$ polymer /g algae and $0.1 \mathrm{~g}$ algae/g bacterial biomass ratio.

- The highest methane yield was found at $560 \pm 24 \mathrm{mlCH}_{4} / \mathrm{gVS}$ when microalgae and anaerobically harvested bacterial biomass were co-digested.

- The short-SRT EBPR process combined with microalgal cultivation can serve as an energy recovery system whereby up to $40 \%$ of the incoming COD is converted to methane through 

anaerobic digestion. Moreover, the COD is successfully removed through the process, thereby leaving only up to $10 \%$ inert COD in the effluent wastewater. However, the optimization of the nutrient balance during the anaerobic digestion by co-digestion with nutrient rich biomass, e.g. microalgae, is important to potentially increase the COD recovery.

\section{Acknowledgements}

Dorottya S. Wágner thanks the European Commission (E4WATER Project, FP7-NMP-2011.3.4-1 grant agreement 280756) for the financial support. Borja Valverde-Pérez thanks the Integrated Water Technology (InWaTech) project (http://www.inwatech.org) for the financial support. The authors thank Kirsa Nørregaard for the help in conducting some of the experiments.

\section{References}

[1] L. Brennan, P. Owende, Biofuels from microalgae-A review of technologies for production, processing, and extractions of biofuels and co-products, Renew. Sustain. Energy Rev. 14 (2010) 557-577.

[2] M.P. Caporgno, A. Taleb, M. Olkiewicz, J. Font, J. Pruvost, J. Legrand, et al., Microalgae cultivation in urban wastewater: Nutrient removal and biomass production for biodiesel and methane, Algal Res. 10 (2015) 232-239.

[3] H. Gao, Y.D. Scherson, G.F. Wells, Towards energy neutral wastewater treatment: methodology and state of the art, Environ. Sci. Process. Impacts. 16 (2014) 1223-1246.

[4] M. Dębowski, M. Zieliński, A. Grala, M. Dudek, Algae biomass as an alternative substrate in biogas production technologies - Review, Renew. Sustain. Energy Rev. 27 (2013) 596-604.

[5] G. Chen, L. Zhao, Y. Qi, Enhancing the productivity of microalgae cultivated in wastewater 
toward biofuel production: A critical review, Appl. Energy. 137 (2015) 282-291.

[6] A.F. Clarens, E.P. Resurreccion, M.A. White, L.M. Colosi, Environmental life cycle comparison of algae to other bioenergy feedstocks, Environ. Sci. Technol. 44 (2010) 18131819.

[7] C.M. Mehta, W.O. Khunjar, V. Nguyen, S. Tait, D.J. Batstone, Technologies to recover nutrients from waste streams: A critical review, Crit. Rev. Environ. Sci. Technol. 45 (2015) 385-427.

[8] D.J. Batstone, T. Hülsen, C.M. Mehta, J. Keller, Platforms for energy and nutrient recovery from domestic wastewater: A review, Chemosphere. 140 (2015) 2-11.

[9] J. Jimenez, M. Miller, C. Bott, S. Murthy, H. De Clippeleir, B. Wett, High-rate activated sludge system for carbon management - Evaluation of crucial process mechanisms and design parameters, Water Res. 87 (2015) 476-482.

[10] H. Ge, D. Batstone, J. Keller, Evaluation of anaerobic digestion processes for short sludgeage waste activated sludge combined with anammox treatment of digestate liquor, Water Sci. Technol. 73 (2016) 1052-1060.

[11] B. Valverde-Pérez, E. Ramin, B.F. Smets, B.G. Plósz, EBP2R - an innovative enhanced biological nutrient recovery activated sludge system to produce growth medium for green microalgae cultivation., Water Res. 68 (2015) 821-830.

[12] A. Oehmen, P.C. Lemos, G. Carvalho, Z. Yuan, J. Keller, L.L. Blackall, et al., Advances in enhanced biological phosphorus removal: From micro to macro scale, Water Res. 41 (2007) 2271-2300. 
[13] M. Wang, C. Park, Investigation of anaerobic digestion of Chlorella sp. and Micractinium sp. grown in high-nitrogen wastewater and their co-digestion with waste activated sludge, Biomass and Bioenergy. 80 (2015) 30-37.

[14] B. Sialve, N. Bernet, O. Bernard, Anaerobic digestion of microalgae as a necessary step to make microalgal biodiesel sustainable, Biotechnol. Adv. 27 (2009) 409-416.

[15] M.P. Caporgno, R. Trobajo, N. Caiola, C. Ibáñez, A. Fabregat, C. Bengoa, Biogas production from sewage sludge and microalgae co-digestion under mesophilic and thermophilic conditions, Renew. Energy. 75 (2015) 374-380.

[16] A.K. Sahu, J. Siljudalen, T. Trydal, B. Rusten, Utilisation of wastewater nutrients for microalgae growth for anaerobic co-digestion, J. Environ. Manage. 122 (2013) 113-120.

[17] K. Kumar, S. Ghosh, I. Angelidaki, S.L. Holdt, D.B. Karakashev, M.A. Morales, et al., Recent developments on biofuels production from microalgae and macroalgae, Renew. Sustain. Energy Rev. 65 (2016) 235-249.

[18] A.J. Ward, D.M. Lewis, F.B. Green, Anaerobic digestion of algae biomass: A review, Algal Res. 5 (2014) 204-214.

[19] M.E. Montingelli, S. Tedesco, A.G. Olabi, Biogas production from algal biomass: A review, Renew. Sustain. Energy Rev. 43 (2015) 961-972.

[20] M.L. Gerardo, S. Van Den Hende, H. Vervaeren, T. Coward, S.C. Skill, Harvesting of microalgae within a biorefinery approach: A review of the developments and case studies from pilot-plants, Algal Res. 11 (2015) 248-262.

[21] F. Roselet, D. Vandamme, M. Roselet, K. Muylaert, P.C. Abreu, Screening of commercial 

natural and synthetic cationic polymers for flocculation of freshwater and marine microalgae and effects of molecular weight and charge density, Algal Res. 10 (2015) 183-188.

[22] L. Gouveia, S. Graça, C. Sousa, L. Ambrosano, B. Ribeiro, E.P. Botrel, et al., Microalgae biomass production using wastewater: Treatment and costs: Scale-up considerations, Algal Res. 16 (2016) 167-176.

[23] R. Gutiérrez, F. Passos, I. Ferrer, E. Uggetti, J. García, Harvesting microalgae from wastewater treatment systems with natural flocculants: Effect on biomass settling and biogas production, Algal Res. 9 (2015) 204-211.

[24] D. Vandamme, I. Foubert, K. Muylaert, Flocculation as a low-cost method for harvesting microalgae for bulk biomass production, Trends Biotechnol. 31 (2013) 233-239.

[25] G. Techobanoglous, F.L. Burton, H.D. Stensel, Wastewater engineering: treatment and reuse, 4th ed., McGraw-Hill, New York, 2004.

[26] D. Manheim, Y. Nelson, Settling and bioflocculation of two species of algae used in wastewater treatment and algae biomass production, Environ. Prog. Sustain. Energy. 32 (2013) 946-954.

[27] D.S. Wágner, B. Valverde-Pérez, M. Sæbø, M.B. de la Sotilla, J. Van Wagenen, B.F. Smets, et al., Towards a consensus-based biokinetic model for green microalgae - the ASM-A, Water Res. 103 (2016) 485-499.

[28] B. Valverde-Pérez, D.S. Wágner, B. Lórant, A. Gülay, B.F. Smets, B.G. Plósz, Short-sludge age EBPR process - Microbial and biochemical process characterisation during reactor startup and operation, Water Res. 104 (2016) 320-329. 
[29] ASTM, Standard practice for coagulation-flocculation jar test of water, 2013.

[30] I. Angelidaki, M. Alves, D. Bolzonella, L. Borzacconi, J.L. Campos, A.J. Guwy, et al., Defining the biomethane potential (BMP) of solid organic wastes and energy crops: A proposed protocol for batch assays, Water Sci. Technol. 59 (2009) 927-934.

[31] J.A. Gerde, L. Yao, J. Lio, Z. Wen, T. Wang, Microalgae flocculation: Impact of flocculant type, algae species and cell concentration, Algal Res. 3 (2014) 30-35.

[32] D. Vandamme, I. Foubert, I. Fraeye, B. Meesschaert, K. Muylaert, Flocculation of Chlorella vulgaris induced by high $\mathrm{pH}$ : Role of magnesium and calcium and practical implications, Bioresour. Technol. 105 (2012) 114-119.

[33] APHA, American Water Works Association, Water Environment Federation, Standard methods for the examination of water and wastewater, Washington DC, 1999.

[34] G.A. Ekama, G.L. Barnard, F.W. Gunthert, P. Krebs, J.A. McCorquodale, D.S. Parker, et al., Secondary Settling Tanks: Theory, Modelling, Design and Operation, International Association on Water Quality, London, UK, 1997.

[35] M. Wang, A.K. Sahu, B. Rusten, C. Park, Anaerobic co-digestion of microalgae Chlorella sp. and waste activated sludge, Bioresour. Technol. 142 (2013) 585-590.

[36] H. Ge, D.J. Batstone, J. Keller, Operating aerobic wastewater treatment at very short sludge ages enables treatment and energy recovery through anaerobic sludge digestion, Water Res. 47 (2013) 6546-6557.

[37] J. Wu, J. Liu, L. Lin, C. Zhang, A. Li, Y. Zhu, et al., Evaluation of several flocculants for flocculating microalgae, Bioresour. Technol. 197 (2015) 495-501. 
535 [38] T. Chatsungnoen, Y. Chisti, Harvesting microalgae by flocculation-sedimentation, Algal Res. 13 (2016) 271-283.

537

538

539

540

541

542

543

544

545

546

547

548

549

550

551

552

553

554

555

[39] D. Vandamme, I. Foubert, B. Meesschaert, K. Muylaert, Flocculation of microalgae using cationic starch, J. Appl. Phycol. 22 (2010) 525-530.

[40] C.O. Letelier-Gordo, S.L. Holdt, D. De Francisci, D.B. Karakashev, I. Angelidaki, Effective harvesting of the microalgae Chlorella protothecoides via bioflocculation with cationic starch, Bioresour. Technol. 167 (2014) 214-218.

[41] M.A. Borowitzka, N.R. Moheimani, Algae for biofuels and energy, Springer, 2013.

[42] L. Gouveia, Micoralgae as a feedstock for biofuels, Springer, 2011.

[43] W. Farooq, M. Moon, B. gon Ryu, W.I. Suh, A. Shrivastav, M.S. Park, et al., Effect of harvesting methods on the reusability of water for cultivation of Chlorella vulgaris, its lipid productivity and biodiesel quality, Algal Res. 8 (2015) 1-7.

[44] L. Christenson, R. Sims, Production and harvesting of microalgae for wastewater treatment, biofuels, and bioproducts., Biotechnol. Adv. 29 (2011) 686-702.

[45] L.L. Fang, B. Valverde-Pérez, A. Damgaard, B.G. Plósz, M. Rygaard, Life cycle assessment as development and decision support tool for wastewater resource recovery technology, Water Res. 88 (2016) 538-549.

[46] I. Udom, B.H. Zaribaf, T. Halfhide, B. Gillie, O. Dalrymple, Q. Zhang, et al., Harvesting microalgae grown on wastewater, Bioresour. Technol. 139 (2013) 101-106.

[47] Z. Wu, Y. Zhu, W. Huang, C. Zhang, T. Li, Y. Zhang, et al., Evaluation of flocculation induced by $\mathrm{pH}$ increase for harvesting microalgae and reuse of flocculated medium, 
Bioresour. Technol. 110 (2012) 496-502.

557 [48] A. Schlesinger, D. Eisenstadt, A. Bar-Gil, H. Carmely, S. Einbinder, J. Gressel, Inexpensive non-toxic flocculation of microalgae contradicts theories; overcoming a major hurdle to bulk algal production, Biotechnol. Adv. 30 (2012) 1023-1030.

[49] M. Henze, M.C.M. Van Loosdrecht, G.A. Ekama, D. Brdjanovic, Biological wastewater treatment : principles, modelling and design, IWA Publishing, UK, 2008.

[50] P.G. Kougias, K. Boe, S. O-Thong, L.A. Kristensen, I. Angelidaki, Anaerobic digestion foaming in full-scale biogas plants: A survey on causes and solutions, Water Sci. Technol. 69 (2014) 889-895.

[51] J. Olsson, M. a. Shabiimam, E. Nehrenheim, E. Thorin, Co-digestion of cultivated microalgae and sewage sludge from municipal waste water treatment, Int. Conf. Appl. Energy. 171 (2013) 1-6.

[52] F. Passos, E. Uggetti, H. Carrère, I. Ferrer, Pretreatment of microalgae to improve biogas production: A review, Bioresour. Technol. 172 (2014) 403-412.

[53] A. Anbalagan, S. Schwede, C.F. Lindberg, E. Nehrenheim, Influence of hydraulic retention time on indigenous microalgae and activated sludge process, Water Res. 91 (2016) 277-284.

[54] M. Kuglarz, D. Karakashev, I. Angelidaki, Microwave and thermal pretreatment as methods for increasing the biogas potential of secondary sludge from municipal wastewater treatment plants, Bioresour. Technol. 134 (2013) 290-297.

[55] D. Bolzonella, P. Pavan, P. Battistoni, F. Cecchi, Mesophilic anaerobic digestion of waste activated sludge: Influence of the solid retention time in the wastewater treatment process, 
Process Biochem. 40 (2005) 1453-1460.

578 [56] F. Passos, S. Astals, I. Ferrer, Anaerobic digestion of microalgal biomass after ultrasound 579 pretreatment, Waste Manag. 34 (2014) 2098-2103.

580 [57] F.A. Meerburg, N. Boon, T. Van Winckel, J.A.R. Vercamer, I. Nopens, S.E. Vlaeminck, 581 Toward energy-neutral wastewater treatment: A high-rate contact stabilization process to

[58] F.A. Meerburg, N. Boon, T. Van Winckel, K.T.G. Pauwels, S.E. Vlaeminck, Live Fast, Die 584 Young: Optimizing Retention Times in High-Rate Contact Stabilization for Maximal Recovery of Organics from Wastewater, Environ. Sci. Technol. 50 (2016) 9781-9790. 